\title{
Landslide features identification and morphology investigation using high-resolution DEM derivatives
}

\author{
Kamila Pawluszek ${ }^{1}$ D
}

Received: 19 July 2017 / Accepted: 20 November 2018 / Published online: 3 December 2018

(C) The Author(s) 2018

\begin{abstract}
In the last decade, development in remote sensing techniques has opened new avenues for studying the evolution of landscapes dominated by mass wasting processes. Conventional methods including field reconnaissance are time-consuming and resource-intensive. Thus, it is worth taking advantage of the high-resolution digital elevation model (HRDEM) to identify landslide features remotely and investigate landslide morphology. This research proposes a new technique of landslide feature identification and morphology mapping using computer-aided methods to enhance the visual interpretation of HRDEM. These computer-aided methods involve deep exploration of topographic information provided by HRDEM. In addition to the HRDEM, nine diverse HRDEM derivatives were used to maximise the morphological information captured by HRDEM. To compact and to better understand the morphological information, original HRDEM derivatives were transformed into the principal component (PC) domain. Based on PC composition provided by three initial PCs, it was possible to identify morphological signatures of landslides and represent them as the detailed landslide surface morphology maps. The presented methodology serves as an alternative means of landslide characterisation. It permitted the evaluation of slope morphology and the ability to reassess recent and future landslide activity on a comparative basis.
\end{abstract}

Keywords Landslide features · Landslide morphology · Landslide inventory map · HRDEM derivatives, landslide activity

Electronic supplementary material The online version of this article (https://doi.org/10.1007/s1106 9-018-3543-1) contains supplementary material, which is available to authorized users.

Kamila Pawluszek

kamila.pawluszek@upwr.edu.pl

1 Institute of Geodesy and Geoinformatics, Wroclaw University of Environmental and Life Sciences, Grunwaldzka 53, 50-357 Wrocław, Poland 


\section{Introduction}

In the last decade, new remote sensing techniques have enabled the improvement in the investigation of the Earth's surface processes. Among these techniques, airborne laser scanning (ALS) is characterised by its usefulness and effectiveness in providing detailed information about surface topography (Tarolli 2014). ALS is now widely applied in landslide studies globally and is undergoing rapid developments. In the literature, there are many examples of using ALS data for various landslide applications covering landslide detection (Chen et al. 2013; Pawluszek and Borkowski 2016; Van Den Eeckhaut et al. 2012; Pawluszek et al. 2018), landslide characterisation (Glenn et al. 2006; Goetz et al. 2014; McKean and Roering 2004; Sato et al. 2007) and landslide susceptibility mapping (Ayalew et al. 2005; Bai et al. 2010; Chalkias et al. 2014; Ermini et al. 2005; Jebur et al. 2014; Mashari et al. 2012; Pawluszek and Borkowski 2017; Pourghasemi et al. 2012).

Furthermore, current improvements in sensor electronics and data processing make it possible to obtain point clouds with resolutions of up to $100 \mathrm{pts} / \mathrm{m}^{2}$, while terrestrial laser scanning (TLS) reaches 50 or even $10,000 \mathrm{pts} / \mathrm{m}^{2}$ (Jaboyedoff et al. 2012). Based on such dense point clouds, high-resolution $(\leq 3 \mathrm{~m})$ digital elevation models (HRDEMs) can be generated (Tarolli 2014). It opens up new ways of investigating landslide phenomena (Jaboyedoff et al. 2012).

Recent developments in remote sensing techniques provide opportunities to obtain an HRDEM from other platforms, such as unmanned aerial vehicles (UAVs). Images taken by UAVs are used to produce high-resolution ortho-mosaics providing an HRDEM (Niethammer et al. 2012). UAVs acquire images in more flexible and cost-effective manners than classical aerial surveys (Stumpf et al. 2013). Therefore, it has met with wide interest among researchers in landslide monitoring (Niethammer et al. 2012). However, some researchers (e.g. Niethammer et al. 2012) have reported on the current limitations of UAVs in the context of landslide studies, this emerging technique seems to be important in the near future as a high-resolution data acquisition technique.

Many countries have created or are creating national and/or regional landslide databases (LDBs). This is a necessary information source for the quantitative zoning of landslide susceptibility to enable effective risk assessment (Van Den Eeckhaut and Hervás 2012). In Poland, there is a "Landslide Counteracting System", the goal of which is to create landslide inventory maps and recognise landslide-prone areas. A geologist carrying out the landslide inventories during field reconnaissance mapped the main landslide features and described the landslide morphology. Furthermore, the representation and interpretation of landslide forms are a fundamental component of any landslide inventory study as the technique to obtain accurate topographical information is a crucial element in the geomorphic assessment process (Miner et al. 2010). This task is time-consuming, resource-intensive and requires considerable effort during fieldwork, especially in forested areas and for complex landslides, where an overview of the entire landslide extent is limited (Borkowski et al. 2011).

Having considered these difficulties relating to conventional techniques and the availability of HRDEM-derived by different platforms, new landslide mapping techniques are being developed. Researchers have attempted to take advantage of HRDEM to map landslide features remotely and to investigate morphology (Guzzetti et al. 2012). McKean and Roering (2004) were probably the first investigators who used HRDEM with $1 \mathrm{~m} \times 1 \mathrm{~m}$ resolution for the landslide features extraction and morphology mapping. They applied diverse morphological statistics to map the local topographic roughness, which allowed 
for the delineation of four kinematic units within the landslide complex near Christchurch, New Zealand. Glenn et al. (2006) applied surface terrain gradients, surface roughness, semi-variance and fractal dimensions to differentiate morphological components within a landslide. They provided insight into the material type and slide activity in southern Idaho, USA. Sato et al. (2007) used topographic information from a HRDEM for a landslide investigation covering an area of $3.8 \mathrm{~km}^{2}$ in the Shirakami Mountains, Japan. They applied terrain gradient, topographic texture and local convexity to distinguish 17 different landforms domains. Booth et al. (2009) applied two standard signal processing techniques to HRDEM to describe the spatial frequencies of morphological features such as hummocky topography, scarps and depleted mass in the Puget Sound Lowlands, Washington and the Tualatin Mountains, Oregon, USA.

In the author's opinion, the completed investigations do not fully extend the information potential provided by HRDEMs. Therefore, this research aims to propose a new technique for landslide morphology mapping by applying computer-aided methods to enhance the visual interpretation of the HRDEM. This computer-aided method involves deep exploration of topographic information provided by HRDEM. In addition to the HRDEM, nine diverse HRDEM derivatives were used to maximise the morphological information captured by HRDEM. To deeply explore morphological information and better understand the relationships between morphological structures, a combination of all HRDEM derivatives in one multi-layer composition was used. To make the morphological information of the HRDEM derivatives more concise, they were transformed into the principal component (PC) domain. Based on the PC representation composed of three initial principal components, it is possible to identify the landslide diagnostic morphological signature. It serves as an effective means of landslide characterisation and permits the evolution of slope morphology to be examined. It allows the prediction of recent and possible future activity of the slide comparatively. This approach can also be the first step in automating the extraction of landslide morphological signatures using the HRDEM.

Two periodically active landslides have been selected as study sites in the Polish Flysch Carpathians. The activation of numerous landslides in 2010 as a result of intense precipitation brought disastrous results. Nearly every year, mass movements are observed, which result in damage and destruction of residential and commercial buildings, transport infrastructure, transmission routes as well as agricultural and forest areas (Poprawa and Rączkowski 2003). Both landslides are located in the Małopolska municipality, where a wide range of slope movement occurs, and permanent monitoring is necessary to assess the hazard.

\section{Landslide conceptualisation}

Within a landslide extent, several features can be distinguished with significantly different morphological signatures. Figure 1 depicts the location and visualisation of the main landslide features (Van den Eeckhaut et al. 2012). The main scarp is located in the upper part of the landslide (IAEG-International Association 1990). It has a steep slope and it is probably the most important feature in landslide recognition. Its shape is often semicircular and has a main direction perpendicular to the direction of the steepest part of the slide (Van Den Eeckhaut et al. 2012). However, the main scarp often transforms into the flanks, which represent the landslide edges. They refer to the side view from the landslide 


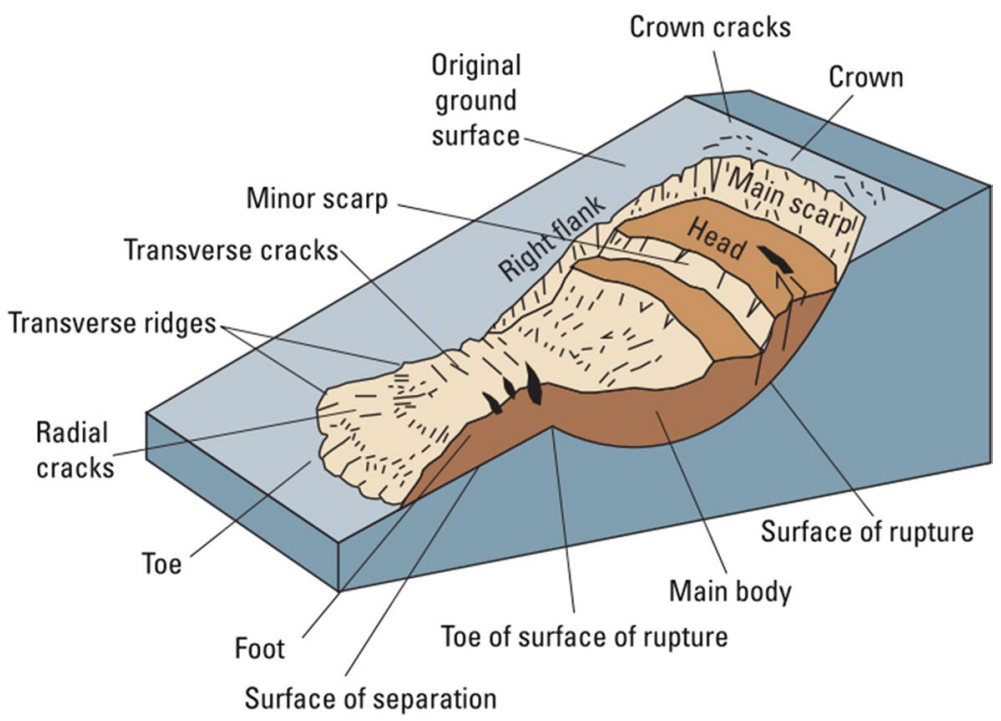

Fig. 1 Conceptualisation of the landslide. A simple illustration of a rotational landslide that has evolved into an earthflow. (Source: Highland and Bobrowsky 2008)

Table 1 Characteristics of landslide features. (Modified based on Van Den Eeckhaut et al. 2012)

\begin{tabular}{ll}
\hline Landslide feature/zone & Characteristics \\
\hline Main scarp & Steep \\
& Semi-circular \\
& Main direction perpendicular to flow direction \\
Flanks & Generally, main direction perpendicular to the \\
& main direction of scarp \\
& Upslope part has significantly higher elevation \\
& than affected area \\
Landslide body/affected area & Downslope part is less clear \\
& High surface roughness \\
Foot & Downslope of main scarp bordered by flanks \\
& Accumulation area is convex in plan and profile \\
& Might border the river or road \\
Minor scarps/crown and transverse cracks & Generally not clear \\
& Main direction perpendicular to flow direction \\
& Not very steep but elevation differences \\
\hline
\end{tabular}

crown (IAEG-International Association 1990). Flanks usually appear perpendicular and downslope to the main scarp. The landslide's body/affected area is the zone where the depleted mass moves and can create radial and transverse cracks. This zone contains some minor scarps and usually appears very rough; however, the roughness can vary significantly within a landslide's body (Van Den Eeckhaut et al. 2012). The last part of the landslide is the landslide toe, which is a curved margin of the displaced material and is far 
distant from the main scarp. Table 1 shows the main morphologic characteristic of some specific landslide features.

\section{ALS data specification and HRDEM generation}

The ALS data were captured at the southeast edge of Rożnów Lake before the catastrophic landslide activity in 2010 (Wojciechowski et al. 2012). The ALS data were obtained during early spring in April 2010, to minimise the influence of vegetation. The data were obtained by an aircraft using the Riegl Lite Mapper 6800 scanning system with a resolution of 4 points per square meter (Borkowski et al. 2011). The ALS data filtering was performed using a method proposed by Borkowski and Jóźków (2008).

The raw data collected using only ground ALS data were used to generate the HRDEM in GRID format. The HRDEM resolution depends on the minimum size of landslide features, which should be investigated. Finding the right resolution of HRDEM depends on different concepts including: the resolution of original data, the size of study area, computer processing power, complexity of the terrain and the purpose of the research (Hengl 2006). It is obvious that the landslide area is complex and in the case of landslide feature recognition, the best resolution is required. Miner et al. (2010) presents the limiting threshold of landslide feature recognition as in the range of 5-10 pixels. The average point spacing (APS) of point cloud used in this paper was 0.5. Having considered such an APS, the complexity of the terrain, the size of the study area and the purpose of this study, the author decided to create the HRDEM with $1 \mathrm{~m}$ resolution. Thus, the resolution of HRDEM allows recognition of landslide feature with a size of $5 \mathrm{~m}$ or greater. Natural neighbour interpolation method was used to prevent the smoothing effect provided by other methods (Tarolli et al. 2012). If the HRDEM is more "rough" and sharp, then a more real representation of Earth's surface is achieved. Figure 2 shows the difference between two resolutions of the HRDEM and their impact on morphological feature detection. It is visible that

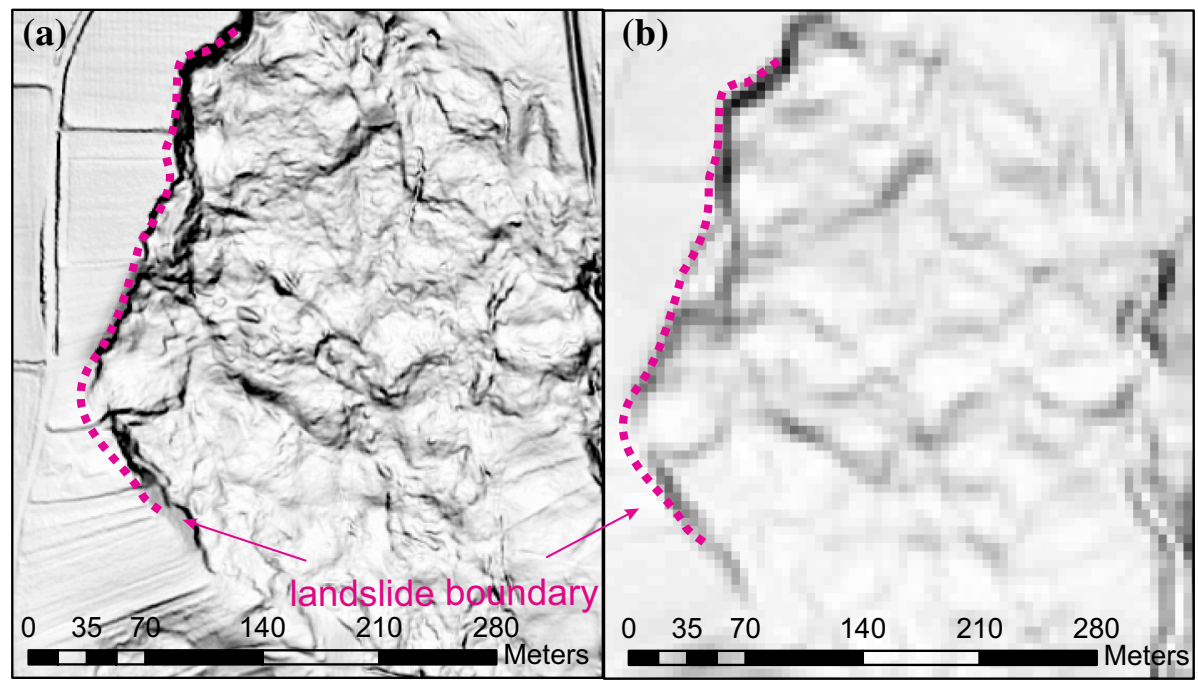

Fig. 2 Difference between $1 \mathrm{~m} \times 1 \mathrm{~m}$ DEM resolution (a) and $5 \mathrm{~m} \times 5 \mathrm{~m}$ DEM resolution (b) 
HRDEM (Fig. 2a) makes it possible to also map smaller convergences/divergences, which are critical for the investigation of landslide morphology (Tarolli et al. 2012).

\section{Landslides and landslide database in Poland}

Landslide Counteracting System (SOPO in Polish) is the existing national landslide database. This inventory project was launched in 2008. The project was designed by the Ministry of Environment and supplied by the National Fund for Environmental Protection and Water Management. The Polish Geological Institute conducted the project with geologic survey tasks. Any information connected with landslide damage or triggering events is documented and stored as attributes in the database. All landslide-related information is validated by experts and uploaded to the database. For instance, documentation of landslide field investigation and its specification, activity state, landslide extent, size, map and photos are available for users to download. The SOPO is ready for use via Web application (http://osuwiska.pgi.gov.pl) and is systematically updated. This data were used for validation of the presented approach.

From the geological perspective, development of landslides in the Polish Flysch Carpathians is favoured by the geological structure formed mainly by flysch rocks involving shale, slate-sandstone and sandstone layers. These rocks are generally covered with a residual soil non-cohesive rock material formed as a result of weathering processes on clay soils of various origins. The thickness of these units can range from several dozen $\mathrm{cm}$ to several metres (Poprawa and Rączkowski 2003). Moreover, landslides in the Carpathians are also favoured by large relative differences in elevation, steep slopes and river erosion.

Slope saturation by water is the primary triggering factor of landslides in the Polish Flysch Carpathians. Saturation can occur in the form of intense rainfall, snowmelt, changes in ground-water levels, and water-level changes along rivers, lakes, etc. However, under Polish weather conditions the landslide-activating factor is mostly related to rainfall. The most dangerous are summer, intense rainfalls which take several or even several dozen days, covering large areas sometimes in almost all Carpathian tributaries of the Vistula River. SOPO services provide special warnings when the amount of continuous rainfall exceeds the specific threshold for triggering landslides. For instance, on 22 of September 2017 SOPO informed that in the case of continuous rainfall exceeding 100-150 mm, shallow landslides can be activated, while for rainfall over $400 \mathrm{~mm}$-large and deep landslides can be activated (http://geoportal.pgi.gov.pl/SOPO/komunikaty).

\section{Characteristics of the study landslides}

Landslide No. 1 selected for analysis is located near the village of Gródek nad Dunajcem in Poland, close to the shore of Rożnów Lake. The landslide covers an area of 37.75 ha with a length of $950 \mathrm{~m}$ and width $533 \mathrm{~m}$. The elevation within the landslide ranges between 276.48 and $435.05 \mathrm{~m}$. The geographical location of this study area is $49^{\circ} 43^{\prime} \mathrm{N}$ to $49^{\circ} 44^{\prime} \mathrm{N}$ latitude and $20^{\circ} 44^{\prime} \mathrm{E}$ to $20^{\circ} 45^{\prime} \mathrm{E}$ longitude. Figure 3 shows the location of the study landslide and its extent.

In the documents created during the field reconnaissance in October 2010, this landslide was hypothesised to be an old landslide reactivated after abundant rainfall in 2010. 


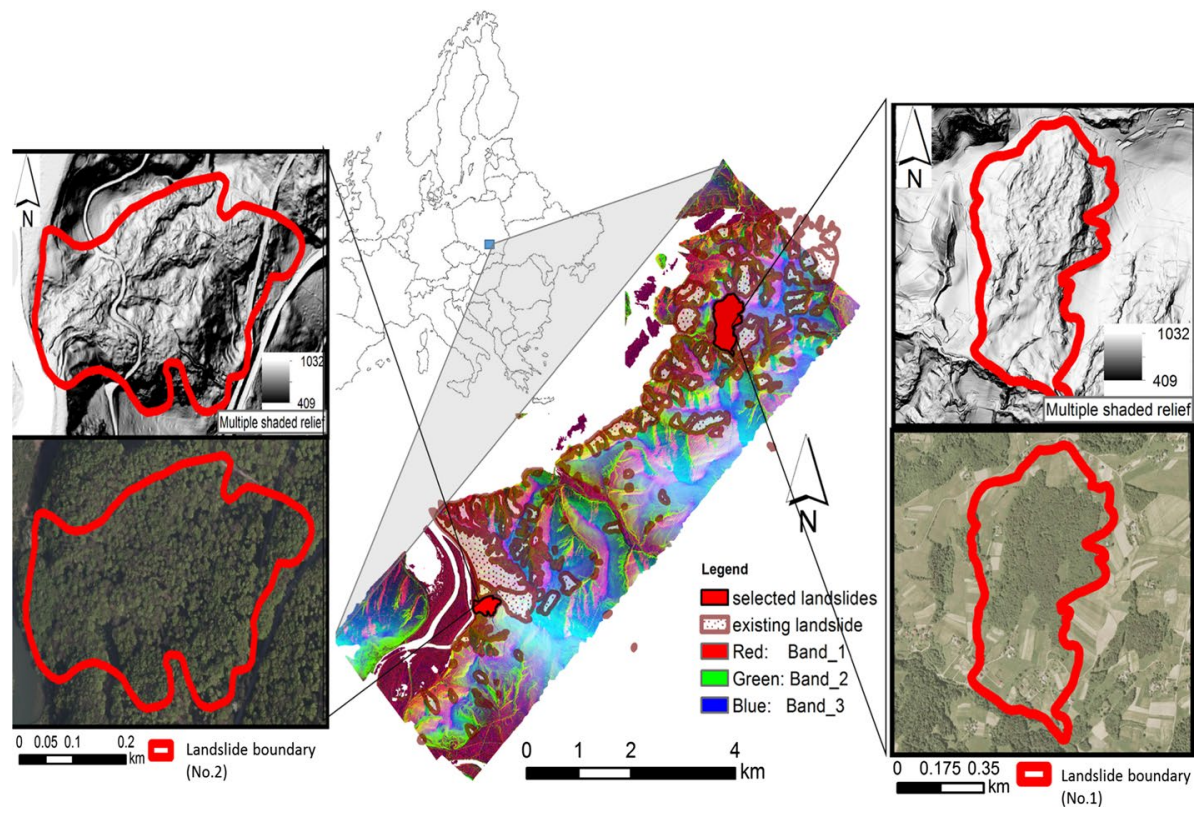

Fig. 3 Location of the study areas. Background RGB representation illustrats principal component composition

Based on these field investigations, the estimated thickness of colluviums is about $30 \mathrm{~m}$. Colluviums in the central part are covered by forest, and in the lower and upper parts they are covered by agricultural areas. From a geological perspective, the landslide surface consists of clay, clay with rubble from the Quaternary period and sandstones and shales of the Eocene period. The depleted mass consists of gravels with clay and rubble rock (Wójcik and Krawczyk 2010). Following Varnes' (1978) classification and the subsequent update from Hungr et al. (2014), the investigated landslide is clay/silt rotational slides (type 11). Landslide No. 1 was selected for this research for multiple reasons. Firstly, based on Landslide Counteracting system (SOPO), the selected landslide is periodically active, and thus various activity states can be observed. Secondly, according to the recommendations of the Polish Geological Institute, the landslide No. 1 should be investigated periodically. However, a significant part of the landslide is covered with forest, and therefore it is very complex to investigate in the field. Furthermore, the presented landslide is an old landslide, which was reactivated after heavy rainfalls in 2010, making the morphology of this landslide interesting to investigate. Also, residential and economic buildings exist in the extent of this landslide. Some of them are in high susceptibility zones; some of them are partly damaged and cannot be inhabited.

Landslide No. 2 selected for analysis is located near the village of Dąbrowa in Poland, close to the Shore of Rożnów Lake. The landslide covers an area of 11.54 ha. The length and the width are about $50 \mathrm{~m}$ and $310 \mathrm{~m}$, respectively. The elevation within the landslide No. 2 ranges between 268.62 and $398.81 \mathrm{~m}$. The geographical location of this study area is $49^{\circ} 41^{\prime} 45^{\prime \prime} \mathrm{N}$ to $49^{\circ} 41^{\prime} 55^{\prime \prime} \mathrm{N}$ latitude and $20^{\circ} 40^{\prime} 20^{\prime \prime} \mathrm{E}$ to $20^{\circ} 40^{\prime} 45^{\prime \prime} \mathrm{E}$ longitude. Figure 3 represents the location of the study landslide No. 2 and its extent. This landslide is slow moving and completely covered by forest making it also very difficult to investigate. According to Varnes' (1978) classification and the update by Hungr et al. (2014), the investigated 
landslide is also clay/silt rotational slide (type 11). In the national landslide database, this landslide was also hypothesised as periodically active. Further reasons to investigate this landslide are the same as in case of landslide No. 1

\section{Methodology}

The landslides examined in this paper are mainly covered with forest. Aerial photo interpretation, which is commonly used for landslide inventories, is not an appropriate tool in these cases. Therefore, visual interpretation of the topographic surface derived from the HRDEM remains the most promising technique. Different HRDEM derivatives were used to maximise and emphasise the morphological information and enhance visual interpretation. It allows the recognition of diverse morphological characteristics by topographicbased analyses and eye inspection. Each of the HRDEM derivatives provides different clues about the nature of the topography. Therefore, observing each HRDEM-derivative separately is complicated and some connection between landslide features cannot easily be observed. Applying many HRDEM derivatives and combining them in one multi-layer composition should be more advantageous. The ALS-derived HRDEM provides precise information about topography and allows identification of different landslide morphologies by applying diverse mathematical operations on the HRDEM. These operations use a window-moving calculation, where the value of the central pixel is replaced by new value using simple combinations of neighbouring cells. These mathematical operations are first- and second-order derivatives and are available in many GIS softwares. ArcGIS is considered especially suitable for the analysis of morphological calculation because of the abundance of tools to handle raster digital models. Therefore, the extended set of HRDEM derivatives was produced using this software. The main description and reference of each HRDEM-derivative used in this paper are presented in Supplementary Material.

Principal component analysis (PCA) was applied to combine them into one composition. Different HRDEM derivatives have different data ranges, therefore before applying PCA it was necessary to normalise the data. Some GIS software does it automatically, others do not. Using ArcGIS, it was necessary to normalise each HRDEM-derivative layer independently. PCA allows the compacting of all morphological information contained in the full data set into a few bands. In this investigation, only three principal components (PCs) were used. PCA is a technique, which analyses the data set where observations are represented by several inter-correlated quantitative variables (Abdi and Williams 2010). The PCA has various applications. Firstly, it reduces the number of variables necessary to describe some phenomena. Secondly, the PCA can be applied to detect certain regularities between variables. Moreover, the basic component where the variance is maximised allows for the verification of detected patterns, relationships and classification of objects in a new space specified by a set of results. From a mathematical point of view, the PCA rotates the coordinate system and creates a new space, where the variation of original data coordinates is maximised. Using this space, the data size can be greatly reduced (Jolliffe 2002).

The PCA is an orthogonal linear transformation of interrelated variables to a new set of uncorrelated variables (new coordinate system), which are called the principal components and are arranged in descending order. It was performed on HRDEM derivatives collected in the matrix $\mathbf{X}$ and centred,

$$
\mathbf{1}^{\mathrm{T}} \mathbf{X}=0
$$


Fig. 4 Methodology flow chart

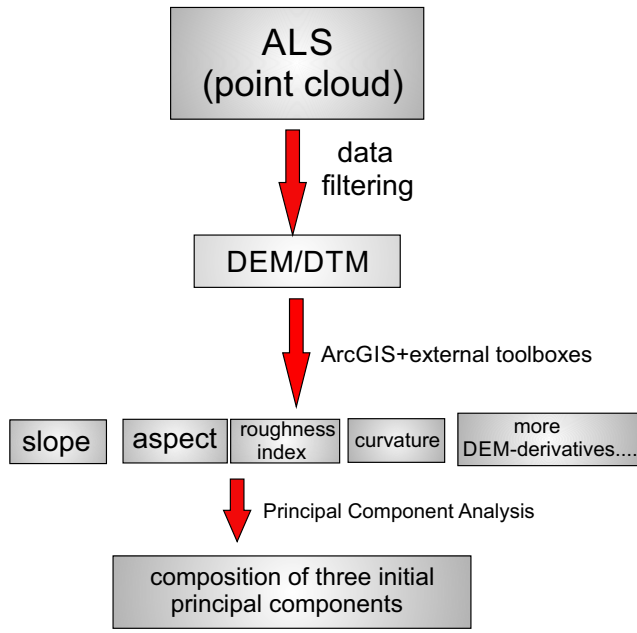

where $\mathbf{1}$ is an $n$-dimensional vector of ones. The principal component decomposition is given by (Jolliffe 2002)

$$
\mathbf{P C s}=\mathbf{X} \cdot \mathbf{V},
$$

where $\mathbf{V}$ is a matrix whose columns are the eigenvectors of the covariance matrix,

$$
\mathbf{C}=\mathbf{X}^{\mathrm{T}} \mathbf{X} /(n-1) .
$$

The orthogonal eigenvector matrix $\mathbf{V}$ is given be the spectral decomposition of the covariance matrix,

$$
\mathbf{C}=\mathbf{V} \Lambda \mathbf{V}^{\mathrm{T}}
$$

where $\boldsymbol{\Lambda}$ is a diagonal matrix of the eigenvalues.

In this research, the composition of the first three PCs was used and interpreted to reveal landslide features. Based on this three-layer PCA-derived morphology image, the main landslide features and extent have been mapped manually. Figure 4 briefly depicts the methodology flow chart.

\section{Results}

\subsection{HRDEM derivatives}

Seven diverse HRDEM derivatives, available in ArcGIS and widely applied in landslide studies, were used. Using ArcGIS, it is also possible to create new HRDEM derivatives or modify these existing ones with scripting. In this study, two external derivatives were utilised in addition to those available in ArcGIS. Namely, topographic position index (TPI) was implemented using the "topography tools" toolbox created by Dilts (2015). Surface relief ratio (SRR) was implemented using the "geomorphometry and gradient metrics" toolbox created by Evans et al. (2014). Their graphical representations are presented in Fig. 5. 

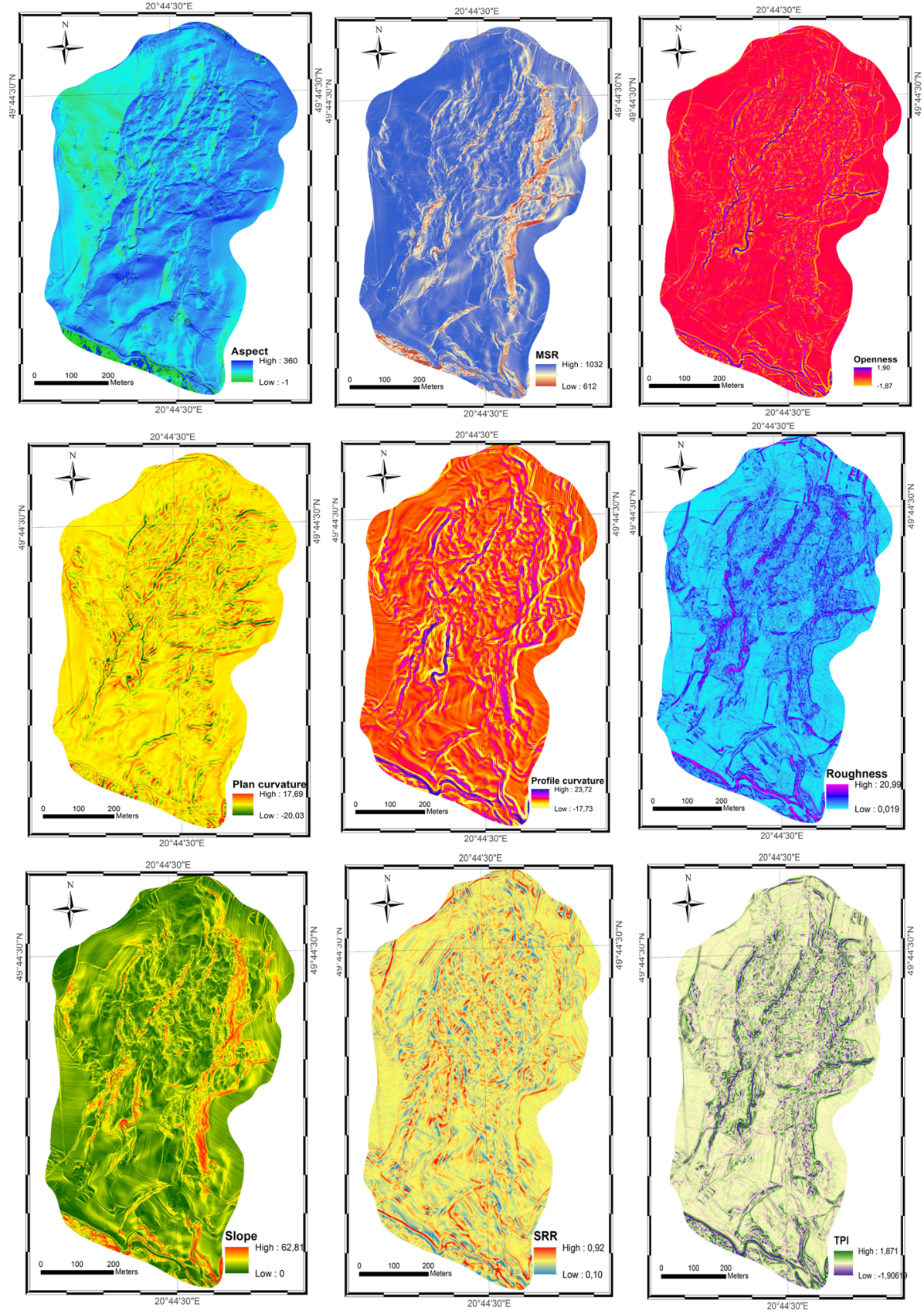

Fig. 5 HRDEM derivatives used for principal component analysis in presented study 


\subsection{Principal component analysis}

Supplementary Material presents a correlation matrix between the HRDEM derivatives. Based on the correlation index, it can be observed that some of the HRDEM derivatives provide redundant information about the surface morphology. Having considered this redundancy, the number of variables taken into account can be reduced by applying PCA. One empirical criterion for principal component reduction requires that principal components should provide at least $80 \%$ of the total variance (Solanas Pérez et al. 2011). To evaluate how much cumulative variance is contained in three principal components, three different strategies were tested. In the first strategy, the area of landslide No. 1 was used, the second strategy used the area of landslide No. 2, and the third strategy used the whole data set acquired during the scanning, which covers an area of $30 \mathrm{~km}^{2}$. Figure 6 shows the amount of cumulative variance in the subsequent principal components for all strategies. The results show that three initial principal components derived from the HRDEM contain $85.1 \%$ of total variance for the first strategy, $86.8 \%$ for the second strategy and $90 \%$ for the third strategy. Based on this it can be concluded that in many cases, using three PC from the whole data set created from the HRDEM derivatives presented in this study meets the empirical criterion for principal component reduction that PCs should provide at least $80 \%$ of the total variance.

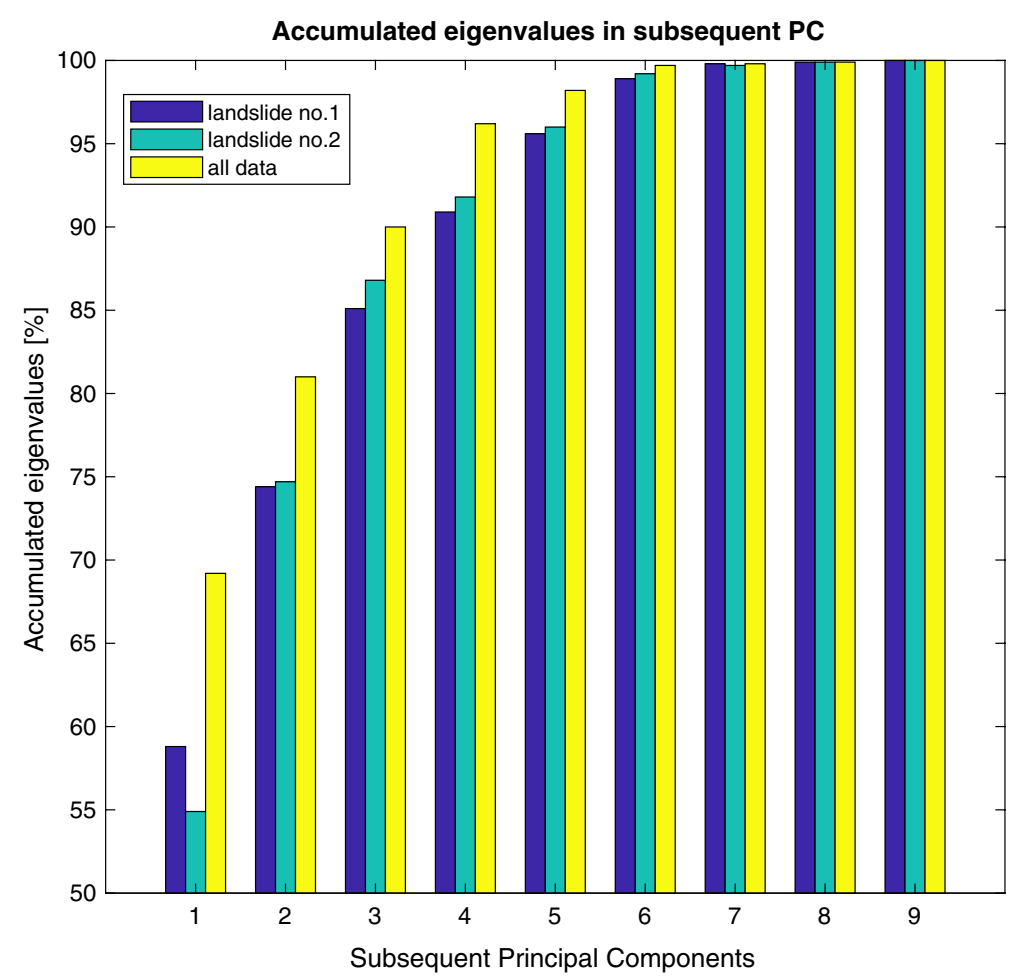

Fig. 6 Cumulative eigenvalues in subsequent principal components 
Table 2 Correlation matrix between the initial principal components and original HRDEM derivatives

\begin{tabular}{lccc}
\hline & $\begin{array}{l}\text { The first principal com- } \\
\text { ponent (red) }\end{array}$ & $\begin{array}{l}\text { The second principal } \\
\text { component (green) }\end{array}$ & $\begin{array}{l}\text { The third principal compo- } \\
\text { nent (blue) }\end{array}$ \\
\hline Aspect & 1.00 & 0.00 & 0.00 \\
Multiple shaded relief & -0.12 & 0.83 & -0.12 \\
Openness & 0.00 & -0.11 & -0.84 \\
Elevation & 0.17 & 0.24 & 0.07 \\
Planar curvature & 0.00 & 0.10 & 0.39 \\
Profile curvature & -0.01 & -0.11 & -0.54 \\
Slope & -0.02 & -0.96 & 0.09 \\
Roughness & -0.03 & -0.58 & -0.03 \\
SRR & 0.00 & 0.06 & 0.74 \\
TPI & 0.00 & 0.11 & 0.93 \\
\hline
\end{tabular}

\subsection{The PC composition}

PCA was used as a tool to transform total variation from 10 original HRDEM derivatives into three bands, which corresponds to the three initial PCs. PCA application permitted the three layers to be easily combined in one PC image as Red-Green-Blue composition. Therefore, using these three initial principal components, the PC composition was provided. To define what morphological information corresponds to these three initial PCs, a correlation matrix between original HRDEM derivatives and the three initial PCs was computed and is presented in Table 2. Having considered only correlation coefficient greater than 0.5 , it can be seen that the first PC corresponds only to the aspect. However, the second PC corresponds to the slope, multiple shaded relief and roughness. The third PC corresponds to the openness, profile curvature, SRR and TPI. The first, second and third PCs are represented by red, green and blue channels, respectively. Figure 7 presents the additive colour mixture and morphological information assigned to these channels.

Figure $8 \mathrm{a}, \mathrm{b}$ presents the PC composition, which contains $85 \%$ and $87 \%$ of total variance of the original HRDEM derivatives for landslide No. 1 and landslide No. 2, respectively. Based on this PC representation, different landslide features and morphologies were identified and mapped by eye inspection (Fig. 8a, b). The main landslide features and zones were manually mapped on PC composition based on the landslide

Fig. 7 Additive colour mixture and corresponding topographic information applied to them

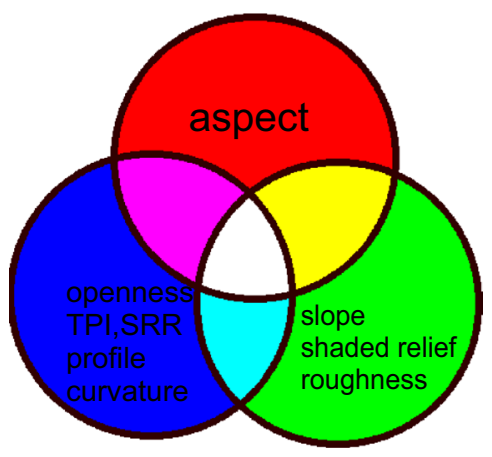



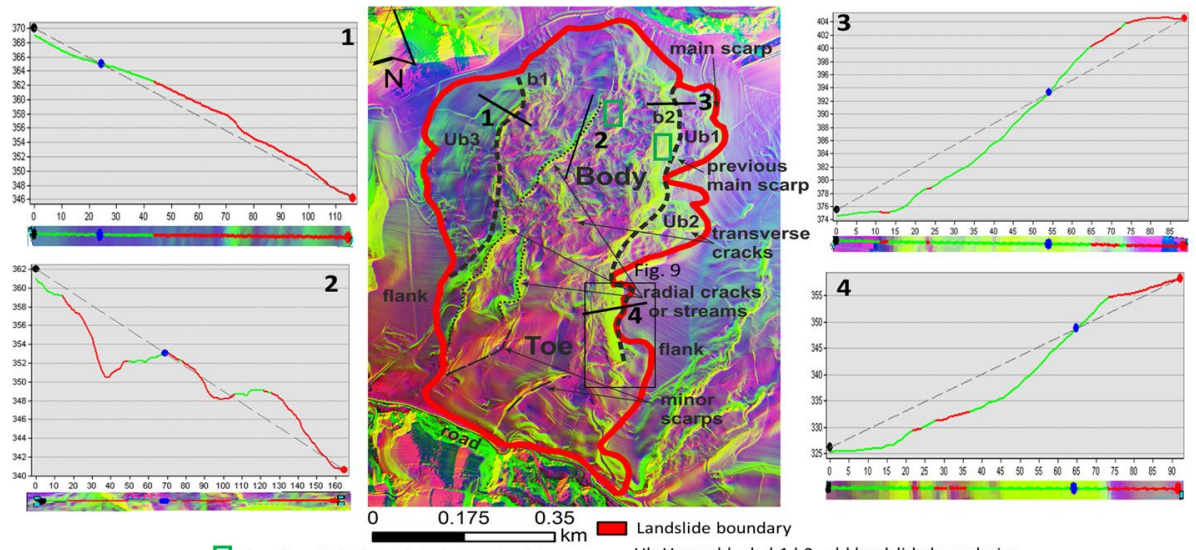

Samples of the landslide feature for histograms Ub-Upper block, b1,b2- old landslide boundaries

(a)
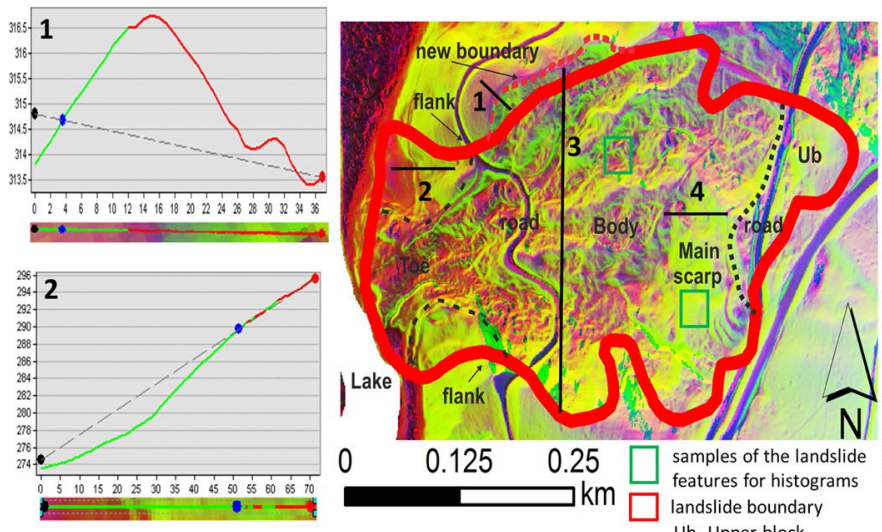

$\mathrm{m}$

samples of the landslide latures for histograms Ub- Upper block

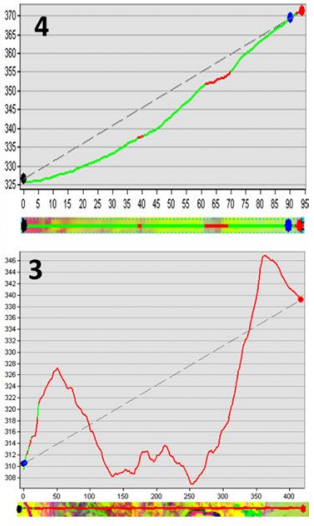

(b)

Fig. 8 a The PC composition and identified landslide features and zones in landslide No. 1. b The PC composition and identified landslide features and zones in landslide No. 2

conceptualisation and characteristic of landslide features. To better examine the PC composition, the elevation profiles across the main landslide features and zones were also created. Colour slices for the profiles are located at the bottom of each elevation profile. Some image samples were also mapped in the area of the landslide body, and main scarp for both landslides and their histograms and statistics are presented in Table 3.

\section{Discussion}

Based on the elevation profiles and colour slices, it is possible to correlate the morphology of the landslide with the colour composition. Analysing the PC composition, yellow and green colours enhance the visibility of the landslide scarps. In the case of landslide No. 1, the boundary was redefined and a new scarp was identified. Therefore, the main 
Table 3 Histograms for each PC component for main scarp and landslide body (for both landslides)

\begin{tabular}{|c|c|c|c|c|c|}
\hline $\begin{array}{l}\text { Land- } \\
\text { slide } \\
\text { feature }\end{array}$ & & Landslide No.1 & Statistics No.1 & Landslide No.2 & Statistics No.2 \\
\hline \multirow[t]{3}{*}{$\begin{array}{l}\text { Main } \\
\text { scarp }\end{array}$} & PC1 & || & $\begin{array}{l}\min =0.64 \\
\max =0.90 \\
\text { mean }=0.79 \\
\text { std. dev. }=0.04\end{array}$ & 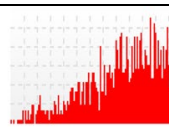 & $\begin{array}{l}\min =0.65 \\
\max =0.92 \\
\text { mean }=0.79 \\
\text { std. dev. }=0.05\end{array}$ \\
\hline & $\mathrm{PC} 2$ & 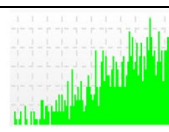 & $\begin{array}{l}\min =0.21 \\
\max =0.60 \\
\text { mean }=0.42 \\
\text { std. dev. }=0.07\end{array}$ & & $\begin{array}{l}\min =0.22 \\
\max =0.72 \\
\text { mean }=0.48 \\
\text { std. dev. }=0.07\end{array}$ \\
\hline & PC3 & ..1 & $\begin{array}{l}\min =1.18 \\
\max =1.40 \\
\text { mean }=1.28 \\
\text { std. dev. }=0.04\end{array}$ & 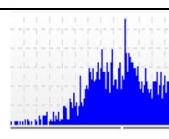 & $\begin{array}{l}\min =1.08 \\
\max =1.31 \\
\operatorname{mean}=1.19 \\
\text { std. dev. }=0.04\end{array}$ \\
\hline \multirow[t]{3}{*}{ body } & $\mathrm{PC} 1$ & & $\begin{array}{l}\min =0.01 \\
\max =1.01 \\
\text { mean }=0.64 \\
\text { std. dev. }=0.14\end{array}$ & & $\begin{array}{l}\min =0.02 \\
\max =1.00 \\
\text { mean }=0.77 \\
\text { std. dev. }=0.11\end{array}$ \\
\hline & $\mathrm{PC} 2$ & & $\begin{array}{l}\min =0.09 \\
\max =0.75 \\
\text { mean }=0.24 \\
\text { std. dev. }=0.08\end{array}$ & $\triangle$ & $\begin{array}{l}\min =0.07 \\
\max =0.51 \\
\text { mean }=0.28 \\
\text { std. dev. }=0.08\end{array}$ \\
\hline & PC3 & & $\begin{array}{l}\min =1.04 \\
\max =1.43 \\
\operatorname{mean}=1.30 \\
\text { std. dev. }=0.05\end{array}$ & & $\begin{array}{l}\min =1.08 \\
\max =1.35 \\
\text { mean }=1.22 \\
\text { std. dev. }=0.04\end{array}$ \\
\hline
\end{tabular}

scarp (based on the previous mapping) has now been replaced. In Fig. 8a (profile 1, 2, 4), one can see that green and yellow colours indicate the areas where topography is upwardly concave. However, green and yellow colours indicate different slope aspects (Fig. 8a, profile 2). On that basis, the boundary between two main expositions of landslide slope was mapped (Fig. 8a) as well as landslide concavities as the radial cracks are easily identified because of their V-shape. Magenta and blue colours indicate the areas where topography is upwardly convex (Fig. 8a, profile 1). Active slides are commonly fresh, and their morphological features are easily identified because they have not been significantly changed by surficial processes such as weathering and erosion (Varnes 1978). Fresh landslides can be observed as having hummocky topography and sharp edges, which are easily seen as colour variations on almost the whole of landslide No. 2 (Fig. 8b) and the central and right upper part of the landslide No. 1 (Fig. 8a). Considering that, it can be stated that this part of landslide No. 2 and almost the whole of landslide No. 1 is fresh based on colour heterogeneity. On the left side of landslide No. 2, significant colour variations and sharp edges are not observed. This part is rather smooth, and it can be concluded that it is an old part of the landslide, where the surface morphology has been changed by environmental or human activities. A similar situation exists at the toe of landslide No. 1, where the morphology has been changed by human activities such as agricultural and/or residential development. It leads to smoother topography and difficulties in landslide feature identification. In contrast, landslide No. 2 (Fig. 8b) is completely covered by forest and almost the whole landslide 
area is represented by topography heterogeneity. The PC representation of the topography provides a useful clue of the landslide's nature and slide movements.

Based on the PC histograms presented in Table 3, it can be observed that each PC histogram for the samples of main scarp is symmetrical and more stretched. In contrast, PC histograms for the samples of landslide body are more concentrated and asymmetric. Histograms for the first and third PC are shifted more towards the right. However, histogram for the second PC is shifted towards the left.

Figure 9 represents the topographic surface representation of the three initial principal components. Figure 9a represents the red channel that corresponds to the first principal component. Figure $9 \mathrm{~b}$ represents the green channel that corresponds to the second initial component. Figure 9c represents the blue channel, which corresponds to the third principal component. The first PC does not provide detailed information about topography; however, the second principal components provide the opportunity to distinguish scarps, which can be observed with a green tone in Fig. 9b. In Fig. 9c, the blue channel components provide detailed information about surface morphology. The forms of small-scale morphologies correspond to secondary mass movements on scarp faces and can be observed as having black colour (Fig. 9c). Based on Fig. 9, it can be stated that subsequent principal components created from the HRDEM derivatives provide more detailed morphological information.

To investigate the results of the presented approach for landslide feature and morphology mapping, other data from independent investigations within the SOPO project (http://osuwi ska.pgi.gov.pl) were collected; however, they are only available for landslide No. 1. These data contain two maps of the landslide in Gródek nad Dunajcem. They were obtained during the field investigations at different times. The first map presented in Fig. 10a (left) was created in October 2010, and the second map presented in Fig. 10b (right) was created in 2014. The first

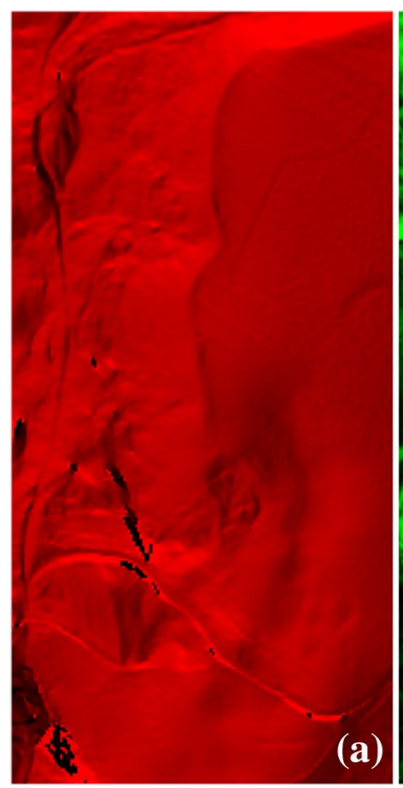

0

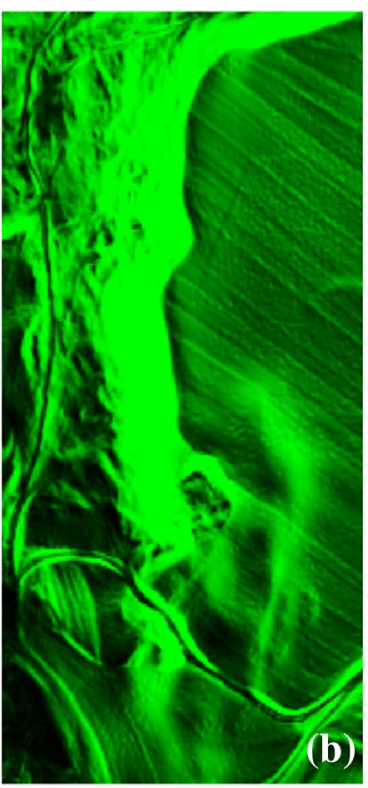

0
62.5

125

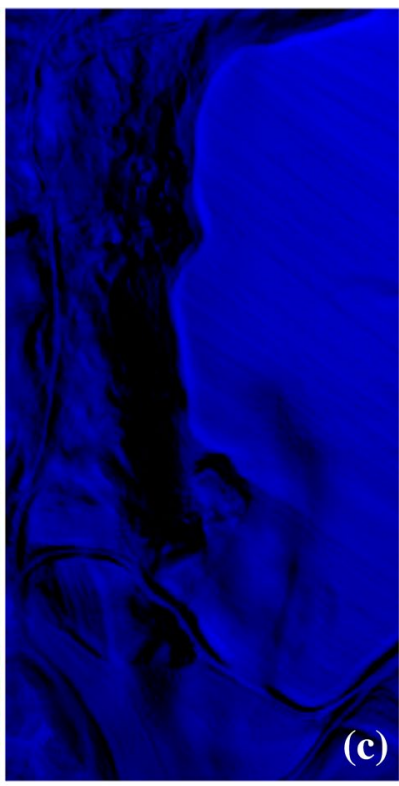

62.5
125

Fig. 9 Representation of three initial principal components 
map was captured from landslide inventory documentation, and the second map was captured from "Landslide Counteracting System", where landslide inventory maps are freely available (Wójcik and Krawczyk 2010; Wójcik et al. 2015a, b). Based on the difference between Figs. 8a and 10, substantial increase in landslide morphology definition and landslide feature recognition can be observed. The approach presented in this study provides more detailed investigation of the landslide because of the increased topographical information provided by $\mathrm{PC}$ analysis and DTM derivatives.

\section{Conclusions}

The HRDEM has opened new avenues to investigate the evolution of landscapes dominated by mass wasting processes. It enabled differentiating morphological signatures within the landslide remotely and provided insight into the activity state. It is particularly beneficial in poorly accessible areas covered by dense vegetation, where aerial photo interpretation commonly applicable to the landslide inventories is not an effective tool.

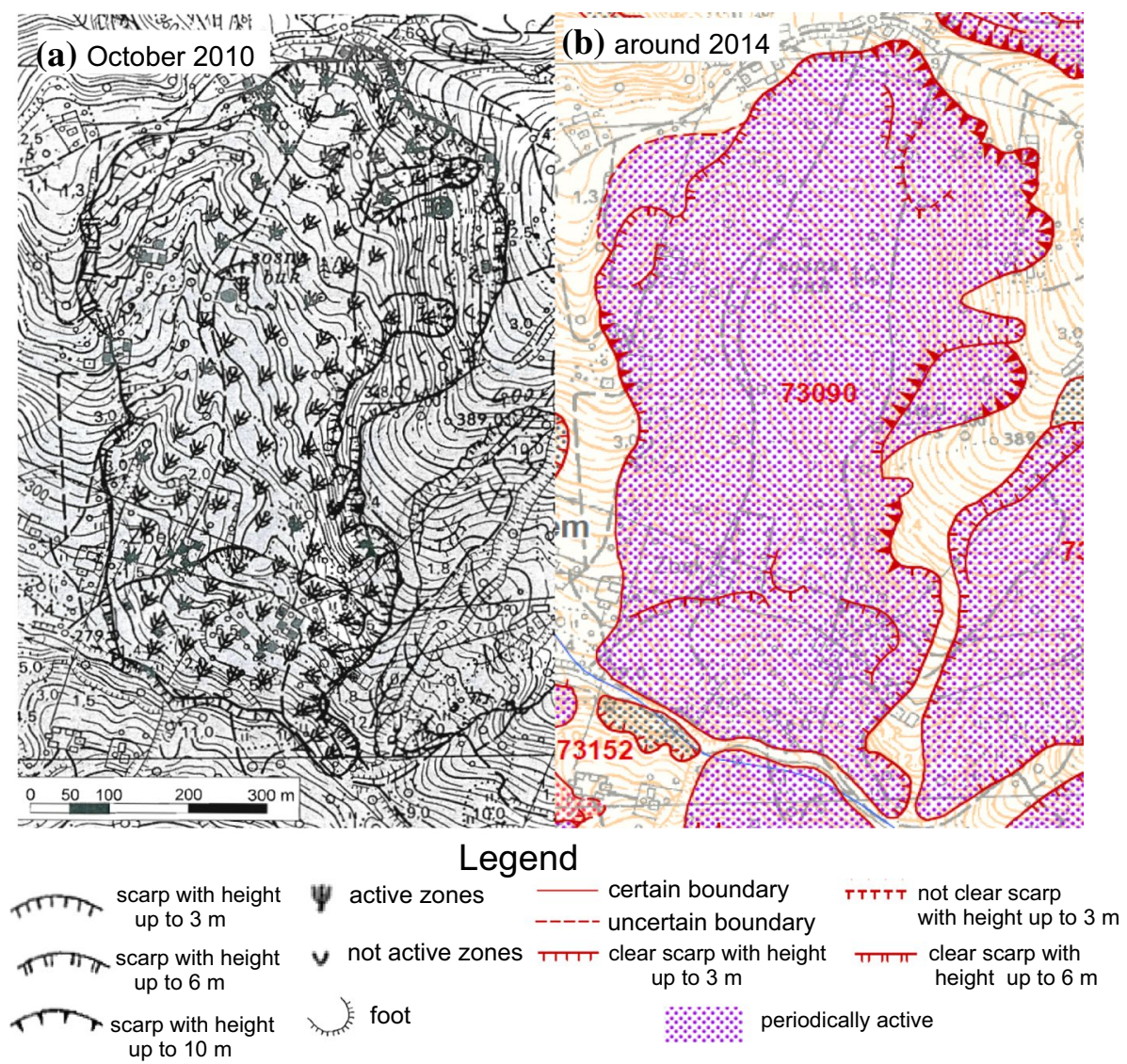

Fig. 10 Two historical maps of landslide No. 1 in Gródek nad Dunajcem. The maps were produced during the field investigations in 2010 (left) and 2014 (right) 
In this paper, a computer-aided method that involves the HRDEM, its derivatives and PCA, allows enhancement of the visual interpretation of the HRDEM and remotely creates detailed landslide surface morphology maps. Diagnostic morphological signatures of landslides identified in this study provide the possibility to investigate the character and the activity of the slide.

Conversely, this technique also has its limitations. Namely, it is only advantageous for mapping recent landslide features, which were not modified by human and/or environmental activities. Uncertainties and difficulties appeared during mapping in older zones. The landslide toe and old boundaries were not evident in the RGB composition because they do not represent the "fresh morphology". Earth's surface processes, occurring on a slope, have been changing the topography over time. Weathering and/or erosion fill the depressions with colluviums and round the scarps. This leads to denudated topography, where landslide features are not easy to identify. The same uncertainties and difficulties also appear during field reconnaissance. However, vegetation changes or diversity observed during field reconnaissance are helpful and can support landslide feature identification in denudated regions.

Conventional methods including field inventories are time-consuming and resourceintensive. The methodology presented in this study could facilitate the production of highquality landslide inventory maps and reduce time and resources required for their compilation and updating. Likewise, landslide feature identification suffers from simplification and requires geomorphological deduction and are, therefore, subjective. Conventional manual aerial photographic interpretation also depends on the skill of the individual observer and the quality of photography. In the presented study, the visualisation of landslide geomorphological characteristics is enhanced and provides improved information by applying the extended set of HRDEM derivatives and the PCA as well as considerably decreases the subjectivity. The usefulness of the HRDEM and its derivatives in landslide phenomena investigations is worth highlighting. Small-scale landslide feature detection would not have been possible during the field reconnaissance or with coarse resolution of DEM $(\mathrm{DEM}>25 \mathrm{~m})$.

Topographic-based analyses in combination with eye inspection demonstrated in this paper do not replace field reconnaissance completely. However, it allows for fast structural characterisations and it can change fieldwork methods, which become part of the validation processes of landslide inventories. It can interactively assist the interpreter during the creation of landslide inventory maps and can facilitate the parameterisation in the final stage of the landslide analysis. This methodology is versatile and can also be applied to investigate other Earth's surface processes in the respective scales. This approach is also the first step in automating the extraction of the landslide morphological signature. The issue of automatic landslide morphological signature extraction is a subject for forthcoming research.

Acknowledgements This research has been supported by National Science Centre of Poland (Grant No. 2017/25/N/ST10/02365). The author would like to thank Prof. Andrzej Borkowski and Dr. Grzegorz Jozkow for their valuable comments on the early draft of the manuscript that helped in improving the original manuscript and two anonymous reviewers for their comprehensive and very helpful reviews.

Open Access This article is distributed under the terms of the Creative Commons Attribution 4.0 International License (http://creativecommons.org/licenses/by/4.0/), which permits unrestricted use, distribution, and reproduction in any medium, provided you give appropriate credit to the original author(s) and the source, provide a link to the Creative Commons license, and indicate if changes were made. 


\section{References}

Abdi H, Williams LJ (2010) Principal component analysis. Wiley Interdiscip Rev Comput Stat 2(4):433459. https://doi.org/10.1002/wics.101

Ayalew L, Yamagishi H, Marui H, Kanno T (2005) Landslides in Sado Island of Japan: part II. GIS-based susceptibility mapping with comparisons of results from two methods and verifications. Eng Geol 81(4):432-445. https://doi.org/10.1016/j.enggeo.2005.08.004

Bai SB, Wang J, Lü GN, Zhou PG, Hou SS, Xu SN (2010) GIS-based logistic regression for landslide susceptibility mapping of the Zhongxian segment in the Three Gorges area, China. Geomorphology 115(1):23-31. https://doi.org/10.1016/j.geomorph.2009.09.025

Booth AM, Roering JJ, Perron JT (2009) Automated landslide mapping using spectral analysis and highresolution topographic data: Puget Sound lowlands, Washington, and Portland Hills, Oregon. Geomorphology 109(3):132-147. https://doi.org/10.1016/j.geomorph.2009.02.027

Borkowski A, Jóźków G (2008) Airborne laser scanning data filtering using flakes. Int Arch Photogramm Rem Sens Spat Inf Sci XXXVII(Part B3b):179-184

Borkowski A, Perski Z, Wojciechowski T, Jóźków G, Wójcik A (2011) Landslides mapping in Rożnów Lake vicinity, Poland using airborne laser scanning data. Acta Geodyn et Geomater 8(3):325-333

Chalkias C, Ferentinou M, Polykretis C (2014) GIS-based landslide susceptibility mapping on the Peloponnese Peninsula, Greece. Geosciences 4(3):176-190. https://doi.org/10.3390/geosciences4030 176

Chen W, Li X, Wang Y, Liu S (2013) Landslide susceptibility mapping using LiDAR and DMC data: a case study in the Three Gorges area, China. Environ Earth Sci 70(2):673-685. https://doi. org/10.1007/s12665-012-2151-8

Dilts TE (2015) Topography tools for ArcGIS 10.1. http://www.arcgis.com/home/item.html?id=b13b3 b40fa3c43d4a23a1a09c5fe96b9. Accessed 26 Dec 2017

Ermini L, Catani F, Casagli N (2005) Artificial neural networks applied to landslide susceptibility assessment. Geomorphology 66(1):327-343. https://doi.org/10.1016/j.geomorph.2004.09.025

Evans JS, Oakleaf J, Cushman SA, Theobald D (2014) An ArcGIS toolbox for surface gradient and geomorphometric modeling, version 2.0-0. http://evansmurphy.wix.com/evansspatial. Accessed 2nd Dec 2015

Gaddis LR, Plant JJ (2001) The roughness of natural terrain: a planetary and remote sensing perspective. J Geophys Res 106(E12):32-777. https://doi.org/10.1029/2000je001429

Glenn NF, Streutker DR, Chadwick DJ, Thackray GD, Dorsch SJ (2006) Analysis of LiDAR-derived topographic information for characterizing and differentiating landslide morphology and activity. Geomorphology 73(1):131-148. https://doi.org/10.1016/j.geomorph.2005.07.006

Goetz JN, Bell R, Brenning A (2014) Could surface roughness be a poor proxy for landslide age? results from the Swabian Alb, Germany. Earth Surf Process Landf 39(12):1697-1704. https://doi. org/10.1002/esp.3630

Guzzetti F, Mondini AC, Cardinali M, Fiorucci F, Santangelo M, Chang KT (2012) Landslide inventory maps: new tools for an old problem. Earth Sci Rev 112(1):42-66. https://doi.org/10.1016/j.earsc irev.2012.02.001

Hengl T (2006) Finding the right pixel size. Comput Geosci 32(9):1283-1298. https://doi.org/10.1016/j. cageo.2005.11.008

Highland L, Bobrowsky PT (2008) The landslide handbook: a guide to understanding landslides. US Geol Survey, Reston, p 129

Hungr O, Leroueil S, Picarelli L (2014) The Varnes classification of landslide types, an update. Landslides 11(2):167-194

IAEG-International Association Engineering Geology Commission on Landslides (1990) Suggested nomenclature for landslides. IAEG Bull 41:13-16. https://doi.org/10.1007/bf02590202

Jaboyedoff M, Oppikofer T, Abellán A, Derron MH, Loye A, Metzger R, Pedrazzini A (2012) Use of LIDAR in landslide investigations: a review. Nat Hazards 61(1):5-28. https://doi.org/10.1007/ s11069-010-9634-2

Jebur MN, Pradhan B, Tehrany MS (2014) Optimization of landslide conditioning factors using very high-resolution airborne laser scanning (LiDAR) data at catchment scale. Rem Sens Environ 152:150-165. https://doi.org/10.1016/j.rse.2014.05.013

Jolliffe I (2002) Principal component analysis. Wiley, New York. https://doi.org/10.1002/9781118445 112.stat06472

Mashari S, Solaimani K, Omidvar E (2012) Landslide susceptibility mapping using multiple regression and GIS tools in Tajan Basin, North of Iran. Environ Nat Resour Res 2(3):43. https://doi. org/10.5539/enrr.v2n3p43 
McKean J, Roering J (2004) Objective landslide detection and surface morphology mapping using highresolution airborne laser altimetry. Geomorphology 57(3):331-351. https://doi.org/10.1016/s0169 $-555 x(03) 00164-8$

Miner AS, Flentje P, Mazengarb C, Windle DJ (2010) Landslide recognition using LiDAR derived digital elevation models-lessons learnt from selected Australian examples. In: Williams AL, Pinches GM, Chin CY, McMorran TJ, Massey CI (eds) Geologically Active: Proceedings of the 11th IAEG Congress of the International Association of Engineering Geology and the Environment, Auckland, New Zealand, 2010. CRC Press, Boca Raton, FL, USA, pp 1-9

Niethammer U, James MR, Rothmund S, Travelletti J, Joswig M (2012) UAV-based remote sensing of the Super-Sauze landslide: evaluation and results. Eng Geol 128:2-11. https://doi.org/10.1016/j. enggeo.2011.03.012

Pawluszek K, Borkowski A (2016) Landslides identification using airborne laser scanning data derived topographic terrain attributes and support vector machine classification. In: The international archives of the photogrammetry, remote sensing and spatial information sciences-XXIII ISPRS congress, Prague, Czech Republic, pp 12-19. https://doi.org/10.5194/isprsarchives-xli-b8-145-2016

Pawluszek K, Borkowski A (2017) Impact of DEM-derived factors and analytical hierarchy process on landslide susceptibility mapping in the region of Rożnów Lake, Poland. Natural Hazards, pp 1-34. https:// doi.org/10.1007/s11069-016-2725-y

Pawluszek K, Borkowski A, Tarolli P, (2018) Sensitivity analysis of automatic landslide mapping: numerical experiments towards the best solution. Landslides 15 (9):1851-1865

Pike RJ, Wilson SE (1971) Elevation relief ratio, hypsometric integral, and geomorphic area altitude analysis. Bull Geol Soc Am 82:1079-1084. https://doi.org/10.1130/0016-7606(1971)82\%5b1079:erhia $\mathrm{g} \% 5 \mathrm{~d} 2.0 . \mathrm{co} ; 2$

Poprawa D, Rączkowski W (2003) Landslide in flysch Carpathians. Przegląd Geol 51(8):685-687 399-412 (in Polish)

Pourghasemi HR, Mohammady M, Pradhan B (2012) Landslide susceptibility mapping using index of entropy and conditional probability models in GIS: Safarood Basin, Iran. Catena 97:71-84. https://doi. org/10.1016/j.catena.2012.05.005

Sato HP, Yagi H, Koarai M, Iwahashi J, Sekiguchi T (2007) Airborne LIDAR data measurement and landform classification mapping in Tomari-no-tai landslide area, Shirakami Mountains, Japan. In: Progress in landslide science. Springer, Berlin, pp 237-249

Solanas Pérez A, Manolov R, Leiva Ureņa D, Richard's MM (2011) Retaining principal components for discrete variables. Anu de Psicol 41(1-3):33-50

Stumpf A, Malet JP, Kerle N, Niethammer U, Rothmund S (2013) Image-based mapping of surface fissures for the investigation of landslide dynamics. Geomorphology 186:12-27. https://doi.org/10.1016/j. geomorph.2012.12.010

Tarolli P (2014) High-resolution topography for understanding Earth surface processes: opportunities and challenges. Geomorphology 216:295-312. https://doi.org/10.1016/j.geomorph.2014.03.008

Tarolli P, Sofia G, Dalla Fontana G (2012) Geomorphic features extraction from high-resolution topography: landslide crowns and bank erosion. Nat Hazards 61(1):65-83. https://doi.org/10.1007/s1106 9-010-9695-2

Van Den Eeckhaut M, Hervás J (2012) State of the art of national landslide databases in Europe and their potential for assessing landslide susceptibility, hazard and risk. Geomorphology 139:545-558. https:// doi.org/10.1016/j.geomorph.2011.12.006

Van Den Eeckhaut M, Poesen J, Verstraeten G, Vanacker V, Moeyersons J, Nyssen J, Van Beek LPH (2005) The effectiveness of hillshade maps and expert knowledge in mapping old deep-seated landslides. Geomorphology 67(3):351-363. https://doi.org/10.1016/j.geomorph.2004.11.001

Van Den Eeckhaut M, Kerle N, Poesen J, Hervás J (2012) Object-oriented identification of forested landslides with derivatives of single pulse LiDAR data. Geomorphology 173:30-42. https://doi. org/10.1016/j.geomorph.2012.05.024

Varnes DJ (1978) Slope movement types and processes. In: Schuster RL, Krizek RJ (eds) Landslides, analysis and control, special report 176: transportation research board. National Academy of Sciences, Washington, pp 11-33

Wojciechowski T, Borkowski A, Perski Z, Wójcik A (2012) Airborne laser scanning data in the study of landslide-case study: landslide in Zbyszyce (Outer Carpathians). Przegląd Geol 60(2):95-102 (in Polish)

Wójcik A, Krawczyk M (2010) Landslide inventory map and description from the fieldwork investigation in 2010 (12-10-032-37). Polish Geological Institute, Warsaw (in Polish)

Wójcik A, Wojciechowski T, Wódka M, Krzysiek U (2015a) Explanations to the landslides inventory maps and areas prone to mass movements in the scale of 1: 10000. Municipality of Gródek nad Dunajcem, 
District: Nowosądecki, Province: Małopolskie. http://geoportal.pgi.gov.pl/portal/page/sopo. Accessed 5 June 2016. (in Polish)

Wójcik A, Wojciechowski T, Wódka M, Krzysiek U (2015b) Landslide inventory map of landslide in Gródek nad Dunajcem in the scale of 1: 10000. Municipality of Gródek nad Dunajcem, District: Nowosądecki, Province: Małopolskie. http://geoportal.pgi.gov.pl/portal/page/sopo. Accessed on 5 June 2016. (in Polish)

Publisher's Note Springer Nature remains neutral with regard to jurisdictional claims in published maps and institutional affiliations. 